\title{
Breeding of comb-wheatgrass (Agropyron pectiniforme Roem. et Schult.) for arid conditions of the steppe zone
}

\author{
S. V. Saprykin ${ }^{1, *}, V . N$ Zolotarev $^{2}$, and I. S. Ivanov ${ }^{1}$ \\ ${ }^{1}$ Voronezh experimental station for perennial grasses-branch of the Federal state budgetary scientific \\ institution "Federal Williams Research Center of Forage Production \& Agroecology", Dokuchaev str., \\ 1, Pavlovsk, Voronezh region, Russia \\ ${ }^{2}$ Federal Williams Research Center of Forage Production \& Agroecology, Nauchny Gorodok str., 1, \\ Lobnya, Moscow region, Russia
}

\begin{abstract}
In the context of the progressive trend of climate aridization of the main agricultural regions in the forest-steppe and steppe zones, the problem of increasing and stabilizing the high productivity of forage crops is becoming more acute. Perennial grasses are the most affordable and stable source of cheap plant feed, and a means of preserving soil fertility during intensive farming, which has an anthropogenic negative impact on agricultural ecosystems. Perennial grasses play a special role as a biological means of counteracting the degradation of biological, water and physical and agrochemical properties of soils, the processes of their dehumidification and erosion. In arid climatic conditions, the most effective species of perennial bluegrass grasses is the comb-wheatgrass or broad-spiked wheatgrass (Agropyron pectiniforme Roem. et Schult.). This crop is resistant to extremely stressful conditions for cultivation in arid conditions, high production potential for the production of various types of voluminous feed. The limiting factor for the effective economic use of the comb-wheatgrass is the insufficient number of zoned varieties. At the Voronezh Experimental Station for perennial grasses, active breeding work is underway to develop new varieties of comb-wheatgrass. The results of the assessment of the source material in the collection nursery are presented. The best specimens for the creation of complex hybrid populations for the formation of the polycross nursery have been identified.
\end{abstract}

\section{Introduction}

In recent years, aridity and drought have become major global issues due to their environmental and social and economic consequences. On the one hand, aridity causes a decrease in the biological and economic productivity of terrestrial ecosystems and poses a serious threat to ecological, biogeochemical, and hydrological processes [1]. Projected climate change is global warming (with concomitant changes in hydrological regimes and

\footnotetext{
${ }^{*}$ Corresponding author: gnu@bk.ru
} 
other climatic variables) caused by an increase in the concentration of radiatively active greenhouse gases. Climate models predict that global surface air temperature may increase from $1.8-4.0 \mathrm{C}$ to $4.0-5.8^{\circ} \mathrm{C}$ in the next few decades $[2,3]$. In addition to increasing temperatures and decreasing rainfall, increased frequency, severity and duration of droughts can significantly affect food production. The analysis of the role of climate change trends in crop production revealed the danger of a significant decrease in yield, including due to a reduction in periods of active crop growth, which is probably the result of high temperatures and water stress [4]. The assessment of modeled climate change impacts using statistical and threshold analysis, climate models, and scaling/initialization methods showed a significant shift of all facilities towards a drier climate by the end of the century, and a decrease in herbage productivity on managed (intensive, extensive) pastures [5]. The detrimental impact of climate change on food security can be offset by improved management of crop production, soil and water resources, as well as the introduction of stress-resistant crops and varieties into agricultural production that are able to overcome the negative effects of aridization [6,7]. The climatic risks of reduced crop production can be reduced through more efficient use of naturally occurring genetic resources and result in the development of new varieties, well adapted to natural changes. Thus, in arid conditions, with a decrease in rainfall by $20-30 \%$ in the structure of growth in the production of grain crops, $34 \%$ falls on the use of improved drought-resistant varieties [8].

Against the background of the emerging tendency of xerophytization of the species and varietal composition of agricultural crops in the conditions of aridization of the climate for the dry steppe regions of the country, one of the most promising crops for forage production is wheatgrass, a dense bunchy herbaceous loosely bunched polycarpic. In a practical sense, wheatgrasses are the most suitable forage crops that are resistant to climatic and weather stresses, high adaptive potential for cultivation and production of various types of voluminous forages [9]. Wheatgrasses belongs to tribe Triticeae Dum. of the type subfamily of the family Poaceae Barnh., genus Agropyron (wheatgrass), subgenus Agropyron Nevski. According to the data of The Plant List, the genus Agropyron includes 26 species [10]. In the system proposed by the Federal Research Center N.I.Vavilov AllRussian Institute of Plant Genetic Resources (VIR), there are 24 taxons of the genus Agropyron in the flora of Russia: 11 species and 13 subspecies, belonging to the 3 species, of which two have two subspecies, and A. crictatum s.l. has 11 subspecies [11].

Currently (as of 2020), 10 varieties of comb-wheatgrass (Agropyron pectiniforme Roem. et Schult.), 3 varieties of Siberian wheatgrass (Agropyron sibiricum (Willd.) P. Beav.) and 8 varieties of desert wheatgrass (Agropyron desertorum (Fisch. ex Link) Schult.) are registered in the State Register of Breeding Achievements approved for use in Russia.

For arid conditions, the most effective crop among perennial bluegrass grasses is combwheatgrass (according to GRIN Taxonomy for Plants (2014-05-22) the valid name is Agropyron cristatum subsp. pectinatum var. pectinatum (M. Bieb.) Tzvelev; according to the list of botanical and zoological genera and species provided for by article 1413 of the Civil Code of the Russian Federation of the Ministry of Agriculture of the Russian Federation - Agropyron pectiniforme Roem. et Schult.) (Synonym = A. pectinatum (Bieb.) Beauv. 1812, Ess. Agrost.: 146. - Triticum pectinatum Bieb. - T. imbricatum Bieb. - T. muricatum Link. - T. cristatum (L.) Schreb. var. hirsutum Lindem.: 1893. - Agropyron cristatum (L.) Beauv. subsp. pectinatum (Bieb.) Tzvel.: 1974=Agropyron pectinatum (M.Bieb.) P.Beauv. = of Elymus uralensis subsp. viridiglu European Environment Agency (European Environment Agency). This species of wheatgrass occupies the most extensive range in the wild $[11,12]$. In culture, it also has the highest specific gravity among other wheatgrass species; it also surpasses them in yield [10, 13]. Among the varieties of perennial grasses created at the Voronezh Experimental Station, in 1958 the Pavlovsky 12 
comb-wheatgrass was zoned. Pavlovsky 12 variety belongs to the East European steppe ecological and geographical group of wheatgrass [14], and was created on the basis of the wild population of the Don River floodplain. The variety is characterized by high winter hardiness, drought hardiness, unpretentiousness to cultivation conditions. Under favorable conditions, it provides the yield of air-dry mass up to 3.0-4.0 t/ha, seeds - up to 0.6-0.8 $\mathrm{t} / \mathrm{ha}$. On poor washed-away, stony and sandy soils, it develops a deep and powerful root system, which is a very much multiple of the weight of the aboveground mass [15]. It has a long productive longevity and high competitiveness, for the 10-12th years of use when sowing the Pavlovsky 12 variety in the composition of multi-species grass mixtures, the grass stand consisted almost entirely of wheatgrass. However, in connection with the long-term reproduction of Pavlovsky 12 and changes in climatic conditions and agrotechnical requirements, farming systems over the past 70 years, the issue of developing new varieties of wheatgrass is relevant.

An important task of wheatgrass breeding currently is the creation of intensive-type wheatgrass varieties, geographically and ecologically differentiated, characterized by high plasticity and resistance to stress factors [15]. To expand the amplitude of the genetic diversity of economically valuable traits, it is necessary to involve the initial material of different geographical origin in the breeding process.

\section{Purpose of work}

Creation, reproduction and introduction into production of intensive varieties of combwheatgrass of a new generation, combining early maturity with high drought resistance, having high fodder and seed yield and other positive signs and properties and suitable for use in arid conditions of the steppe zone.

\section{Materials and methods}

The studies were carried out in 2017-2020 in the field crop rotation of the Voronezh Experimental Station for perennial grasses, located near the city of Pavlovsk, Voronezh Region, in the steppe zone of the south of the Central Black Earth Region. In the collection nursery of the initial material, specimens of wheatgrass obtained from the A.I. Baraev Research and Production Center of Grain Farming. The climate of the Voronezh region is characterized by continentality, which intensifies from the northwest to the southeast, with warm summers and rather cold winters. In general, the climatic conditions are favorable for the cultivation of most crops. The main limiting factor for the cultivation of agricultural crops is insufficient moisture supply. The total amount of rainfall on average per year is $570 \mathrm{~mm}$ in the north and $420 \mathrm{~mm}$ in the south of the region. From May to September, rainfall is $240 \mathrm{~mm}$, during the dry period rainfall is $136-179 \mathrm{~mm}$. A characteristic feature is the unevenness of rainfall over the years and seasons. The average annual air temperature varies from $+5^{\circ} \mathrm{C}$ in the north, to $+7^{\circ} \mathrm{C}$ in its southern regions. The lowest temperature drops to $-40^{\circ}$, the highest is $+40^{\circ}$ (the absolute maximum in the south of the region is $+42^{\circ}$ ), the sum of active temperatures ranges from $2600^{\circ} \mathrm{C}$ to $3000^{\circ} \mathrm{C}$. Droughts and dry winds are observed almost every year. Droughts are very dynamic (May, June, July), in the southern regions their duration reaches 70-80 days. Every third year they are intense.

The research was carried out in uncovered single-species crops in breeding and collection nurseries. All records and observations were carried out using guidelines for the study of the world collection of perennial forage plants, breeding of perennial grasses and guidelines for the breeding of perennial grasses. Breeding nurseries were established in a field crop rotation in a wide-row and continuous way. The soil cover of the field plot is 
ordinary medium-thick, medium-loamy, thin-humus chernozem. The content of $\mathrm{P}_{2} \mathrm{O}_{5}$ in soil is average, $\mathrm{K}_{2} \mathrm{O}$ - increased. Plot area is $5-10 \mathrm{~m}^{2}$, Pavlovsky 12 variety was used as a standard.

Statistical processing of the experimental data was carried out by the method of analysis of variance based on the method of B.A. Dospekhova (1985) on a PC using Excel programs from the Microsoft Office Word 2007 application package.

\section{Results and discussion}

In previous years, various breeding methods helped to obtained breeding material, which was tested at different levels of the breeding process. Competitive variety testing was completed in 2019. According to the research carried out, it was found that the best variety of comb-wheatgrass is Pridonsky variety, which was named Nenarokovsky when transferred to the State Commission; it has an excess of the standard for the yield of green and dry matter by 11.4 and $12.1 \%$, respectively, and was transferred to the State Commission for registration in 2020 [15].

The work on creating for the conditions of the Central Black Earth Region a new promising breeding material for wheatgrass with high potential productivity and resistance to the stress effects of abiotic and biotic environmental factors continues. In 2020, a fouryear study of the comb-wheatgrass collection provided by the A.I. Baraev Research and Production Center of Grain Farming (Kazakhstan). Phenological observations, cares, the nature of regrowth in spring and after each mowing, the height of forage grass stands (by mowing), accounting for fodder mass and seed yield were carried out in the field at the breeding nursery during the growing season of 2017-2020.

The meteorological conditions of the growing seasons were significantly different, which made it possible to reveal the differences between the studied varieties and the standard. In terms of meteorological conditions, in general, 2017 was relatively favorable for the germination, growth and development of perennial grasses. The winter reserve of productive moisture was the highest over the years of the experiment (Table 1). Sowing was carried out in the 2nd decade of April 2017. The rainfall in April-May (74.7 mm) contributed to the obtaining of good seedlings. Seedlings appeared in early May, tillering began in June, and by the end of the growing season, the crops had formed well-developed grass stands. The condition of the plants before leaving for winter was assessed as good.

Table 1. Hydrothermal conditions during the growing season of wheatgrass.

\begin{tabular}{|c|c|c|c|c|c|c|c|}
\hline \multirow{2}{*}{ Year } & \multirow{2}{*}{ Indicators } & \multicolumn{6}{|c|}{ Month } \\
\hline & & April & May & June & July & August & September \\
\hline \multirow{5}{*}{ 홍 } & Rainfall, mm & 29.4 & 45.3 & 21.0 & 19.5 & 5.4 & 50.0 \\
\hline & $\%$ of the rate & 79.4 & 89.0 & 34.3 & 31.9 & 8.4 & 135.0 \\
\hline & Air temperature, ${ }^{\circ} \mathrm{C}$ & 9.5 & 19.2 & 21.7 & 21.5 & 24.1 & 17.2 \\
\hline & Departure from the norm, ${ }^{\circ} \mathrm{C}$ & +2.6 & +4.1 & +2.7 & +2.7 & +4.2 & +3.6 \\
\hline & $\begin{array}{c}\text { Productive moisture reserves in } \\
\text { the layer, } \mathrm{mm}: 0-20 \mathrm{~cm} \text {. } \\
0-100 \mathrm{~cm}\end{array}$ & $\begin{array}{c}28.4 \\
129.8 \\
\end{array}$ & $\begin{array}{l}15.4 \\
80.6 \\
\end{array}$ & $\begin{array}{l}13.5 \\
85.0 \\
\end{array}$ & $\begin{array}{l}10.7 \\
78.8 \\
\end{array}$ & $\begin{array}{c}0.8 \\
27.7 \\
\end{array}$ & $\begin{array}{l}15.4 \\
81.9 \\
\end{array}$ \\
\hline \multirow{5}{*}{$\stackrel{\infty}{\stackrel{\sim}{\sigma}}$} & Rainfall, $\mathrm{mm}$ & 23.3 & 12.5 & 18.7 & 119.3 & 9.5 & 48.2 \\
\hline & $\%$ of the rate & 63.0 & 24.5 & 30.6 & 198.0 & 15.0 & 130.0 \\
\hline & Air temperature, ${ }^{\circ} \mathrm{C}$ & 10.6 & 21.5 & 23.0 & 24.7 & 23.6 & 18.0 \\
\hline & Departure from the norm, ${ }^{\circ} \mathrm{C}$ & +3.7 & +6.4 & +4.0 & +3.7 & +3.7 & +4.4 \\
\hline & $\begin{array}{l}\text { Productive moisture reserves in } \\
\text { the layer, } \mathrm{mm}: 0-20 \mathrm{~cm} \text {. } \\
0-100 \mathrm{~cm}\end{array}$ & $\begin{array}{c}21.7 \\
108.5\end{array}$ & $\begin{array}{l}15.3 \\
92.7\end{array}$ & $\begin{array}{c}5.1 \\
69.0\end{array}$ & $\begin{array}{c}0.2 \\
36.4\end{array}$ & $\begin{array}{c}5.4 \\
71.4\end{array}$ & $\begin{array}{l}12.5 \\
67.6\end{array}$ \\
\hline
\end{tabular}


Table 1. Continued.

\begin{tabular}{|c|c|c|c|c|c|c|c|}
\hline \multirow{5}{*}{$\stackrel{\curvearrowright}{\stackrel{0}{0}}$} & Rainfall, $\mathrm{mm}$ & 17.9 & 87.6 & 29.8 & 114.9 & 33.5 & 12.7 \\
\hline & $\%$ of the rate & 48.3 & 171.8 & 48.9 & 188.0 & 52.0 & 34.0 \\
\hline & Air temperature, ${ }^{\circ} \mathrm{C}$ & 11.5 & 21.7 & 25.9 & 22.1 & 22.0 & 15.6 \\
\hline & Departure from the norm, ${ }^{\circ} \mathrm{C}$ & +4.6 & +6.6 & +6.9 & +1.1 & +2.1 & +2.0 \\
\hline & $\begin{array}{l}\text { Productive moisture reserves in } \\
\text { the layer, } \mathrm{mm}: 0-20 \mathrm{~cm} . \\
0-100 \mathrm{~cm}\end{array}$ & $\begin{array}{c}20.7 \\
103.0\end{array}$ & $\begin{array}{l}11.2 \\
84.9 \\
\end{array}$ & $\begin{array}{c}0.7 \\
60.6\end{array}$ & $\begin{array}{c}9.1 \\
44.0\end{array}$ & $\begin{array}{l}13.8 \\
78.8\end{array}$ & $\begin{array}{c}0 \\
8.6\end{array}$ \\
\hline \multirow{5}{*}{ હે } & Rainfall, mm & 30.8 & 44.4 & 29.5 & 12.5 & 8.8 & 1.0 \\
\hline & $\%$ of the rate & 83.0 & 87.0 & 48.4 & 20.4 & 13.7 & 2.7 \\
\hline & Air temperature, ${ }^{\circ} \mathrm{C}$ & 9.8 & 14.8 & 24.9 & 26.6 & 24.5 & 18.5 \\
\hline & Departure from the norm, ${ }^{\circ} \mathrm{C}$ & +2.9 & -0.3 & +5.1 & +5.6 & +4.6 & +4.9 \\
\hline & $\begin{array}{l}\text { Productive moisture reserves in } \\
\text { the layer, } m m: 0-20 \mathrm{~cm} \text {. } \\
0-100 \mathrm{~cm}\end{array}$ & $\begin{array}{c}20.9 \\
106.1\end{array}$ & $\begin{array}{l}19.1 \\
89.5\end{array}$ & $\begin{array}{c}9.4 \\
61.0\end{array}$ & $\begin{array}{c}0.5 \\
27.7\end{array}$ & $\begin{array}{c}0 \\
5.2\end{array}$ & $\begin{array}{c}0 \\
3.5\end{array}$ \\
\hline
\end{tabular}

The winter reserve of productive moisture in 2018-2020 in the meter layer of soil was (103.0-108.5 mm). However, during the growing season, the temperature regime was increased and was characterized by instability, and the rainfall was uneven in its distribution over months and decades. The temperature during the formation of the first cut was higher than the average long-term norms, the excess of which was 3.7-6.4 in AprilMay in 2018 , and $4.6-6.6^{\circ} \mathrm{C}$, in April 2020 by $+2.9^{\circ} \mathrm{C}$, and in May there was a decrease to $0.3^{\circ} \mathrm{C}$ from the average long-term norms.

The beginning of spring regrowth of plants 2-4 years of age was noted on March 27 31. The interphase period "regrowth - flowering" was leveled between the specimens and the standard, its duration was 62-66 days. Evaluation of plant height showed that most of the studied varieties in the first cut, according to the average indicators of a three-year study, formed grass stands with an average height of $77.3-86.0 \mathrm{~cm}$, of which only 3 specimens slightly exceeded the standard $85.0 \mathrm{~cm}$ (Table 2).

Table 2. Height of forage grasses of wheatgrass varieties (sowing in 2017, records in 2018-2020).

\begin{tabular}{|c|c|c|c|c|c|c|c|}
\hline \multirow{3}{*}{ Name of specimens } & \multicolumn{4}{|c|}{ first mowing } & \multicolumn{3}{|c|}{ second mowing } \\
\hline & \multicolumn{7}{|c|}{ Years of life } \\
\hline & 2 & 3 & 4 & Medium & 2 & 3 & Medium \\
\hline $\begin{array}{c}\begin{array}{c}\text { St. Pavlovsky } 12 \\
\text { variety }\end{array} \\
\end{array}$ & 81.5 & 85.0 & 88.4 & 85.0 & 45.5 & 43.2 & 44.4 \\
\hline Batyr variety & 75.8 & 75.4 & 80.8 & 77.3 & 46.2 & 33.0 & 39.6 \\
\hline Karabalyk 202 variety & 75.0 & 80.6 & 85.2 & 80.3 & 46.0 & 31.0 & 38.5 \\
\hline $\begin{array}{c}\text { Shortandinsky broad- } \\
\text { spiked variety }\end{array}$ & 81.5 & 85.2 & 89.2 & 85.3 & 40.0 & 35.0 & 37.5 \\
\hline Burabay variety & 78.5 & 82.6 & 78.6 & 79.9 & 42.0 & 31.6 & 36.8 \\
\hline SGP KL-1565 & 82.0 & 82.8 & 81.4 & 82.1 & 38.0 & 37.2 & 37.6 \\
\hline SGP KL-1538 & 80.5 & 83.8 & 84.0 & 82.8 & 37.0 & 37.8 & 37.4 \\
\hline SGP KL-1540 & 81.5 & 77.2 & 81.4 & 80.0 & 38.0 & 36.6 & 37.3 \\
\hline SGP KL-1560 & 82.5 & 83.4 & 85.8 & 83.9 & 38.0 & 44.2 & 41.1 \\
\hline SGP KL-1561 & 81.5 & 86.2 & 90.4 & 86.0 & 47.0 & 36.8 & 41.9 \\
\hline SGP KL-1564 & 82.0 & 88.4 & 85.4 & 85.3 & 41.0 & 33.6 & 37.3 \\
\hline SGP KL-1562 & 77.5 & 77.8 & 82.4 & 79.2 & 38.0 & 33.8 & 35.9 \\
\hline SGP KL-1557 & 81.5 & 79.6 & 84.8 & 81.0 & 38.0 & 43.2 & 40.6 \\
\hline SGP KL-1545 & 78.5 & 76.8 & 84.0 & 79.8 & 35.0 & 35.8 & 35.4 \\
\hline $\mathrm{NSR}_{05}$ & 6.18 & 6.23 & 6.52 & 6.31 & 3.23 & 3.01 & 3.17 \\
\hline
\end{tabular}

The second mowing was formed only in 2018 and 2019, the average height for two years in the studied specimens was in the range of 35.4-41.9 $\mathrm{cm}$ and did not exceed the corresponding values of $44.4 \mathrm{~cm}$ for the standard. The reason for the absence of the second 
mowing, as noted above, was the uneven distribution of rainfall by months and high temperatures. The amount of rainfall in June, July and August, in 2018 and 2019, contributed to the formation of the second mowing, they fell only in July, respectively, 198 and $188 \%$ of the long-term norm. In the severely arid year of $2020,50.8 \mathrm{~mm}$ fell during these months, the shortage of rainfall was $135.2 \mathrm{~mm}$, i.e., each hectare did not receive additional 1,352 tons of water. The uneven distribution of rainfall over the years and high temperatures adversely affected the overall productivity of green mass according to the standard and all specimens (Table 3). The highest yield was obtained in 2 years of plant life. In the third and fourth years of life, the yield of all specimens decreased. Thus, the standard's yield of green mass, respectively, was 20.04, 12.48 and $7.48 \mathrm{t} / \mathrm{ha}$, respectively, i.e., a decrease was noted every year by one third. In our opinion, the yield decline was due to a lack of moisture. This restrained growth processes; during periods of drought, the leaves were observed to dry out, which negatively affected the formation of energy reserves of plants for overwintering and active regrowth next spring. The amount of rainfall and reserves of productive moisture are of great importance for plants, the optimal content of which in spring in a meter layer of soil should be $170-175 \mathrm{~mm}$. The initial period of regrowth and the volume of the yield are positively influenced by the amount of rainfall in the winter period, and during the growing season and their distribution by months and phases of plant development.

Yield is one of the factors that can characterize the resistance of the specimens to biotic and abiotic factors. In the breeding nursery, out of 20 specimens of wheatgrass, 2 specimens were isolated according to the productivity of green mass according to the average three-year data, which exceeded the standard by more than 5\%. As noted above, starting from the third year of life, there was a decrease in the yield of all specimens. In the severely arid year of 2020, when only one cut was obtained, the yield of green mass of all specimens is significantly lower than the two previous years. The reason for the absence of the second moving was the uneven distribution of rainfall by months and high temperatures. The amount of rainfall in June, July and August fell $50.8 \mathrm{~mm}$, the shortage of rainfall in 2020 was $135.2 \mathrm{~mm}$, i.e., each hectare did not receive additional 1352 tons of water. The relative humidity of the air has a great influence on the yield of forage and seed productivity, which in 2020 during atmospheric drought and dry winds on some days decreased to $30 \%$, which increased the coefficient of water consumption and evaporation of rainfall from the soil surface.

Table 3. Forage yield of the best specimens in the collection nursery of wheatgrass (sowing in 2017, records in 2018-2020).

\begin{tabular}{|c|c|c|c|c|c|c|c|c|c|}
\hline \multirow{2}{*}{$\begin{array}{c}\text { Item } \\
\text { No. }\end{array}$} & \multirow{2}{*}{ Specimen } & \multicolumn{2}{c|}{ 2 year of life } & \multicolumn{2}{c|}{ 3 year of life } & \multicolumn{2}{c|}{ 4 year of life } & \multicolumn{2}{c|}{ Year average } \\
\cline { 2 - 10 } & & $(\mathrm{t} / \mathrm{ha})$ & $+/-\mathrm{t}$ & $(\mathrm{t} / \mathrm{ha})$ & $+/-\mathrm{t}$ & $(\mathrm{t} / \mathrm{ha})$ & $+/-\mathrm{t}$ & \multicolumn{1}{c|}{$\mathrm{t} / \mathrm{ha})$} & $+/-\mathrm{t}$ \\
\hline $\mathbf{S t}$ & Pavlovsky 12 & $\mathbf{2 0 . 0 4}$ & $\mathbf{0}$ & $\mathbf{1 2 . 4 8}$ & $\mathbf{0}$ & $\mathbf{7 . 4 8}$ & $\mathbf{0}$ & $\mathbf{1 3 . 3 1}$ & $\mathbf{0}$ \\
\hline 1 & Batyr variety & 24.10 & +4.06 & 10.00 & -2.48 & 8.50 & +1.02 & 14.20 & +0.89 \\
\hline 2 & Karabalykskiy 202 variety & 12.72 & -7.32 & 10.58 & -1.90 & 10.30 & +2.82 & 11.20 & -2.11 \\
\hline 3 & $\begin{array}{c}\text { Shortandinskiy broad- } \\
\text { spiked variety }\end{array}$ & 14.36 & -5.68 & 11.96 & -0.52 & 10.78 & +3.30 & 12.37 & -0.94 \\
\hline 4 & Burabay variety & 15.32 & -4.72 & 10.80 & -1.68 & 7.58 & +0.10 & 11.23 & -2.08 \\
\hline 5. & SGP KL-1565 & 17.86 & -2.18 & 11.72 & -0.76 & 7.80 & +0.32 & 12.46 & -0.85 \\
\hline 6 & SGP KL-1538 & 15.70 & -4.34 & 9.98 & -2.50 & 7.76 & +0.28 & 11.15 & -2.16 \\
\hline 9 & SGP KL-1540 & 16.86 & -3.18 & 10.46 & -2.02 & 7.72 & +0.24 & 11.68 & -1.63 \\
\hline 15 & SGP KL-1560 & 17.12 & -2.92 & 11.40 & -1.08 & 9.10 & +1.62 & 12.54 & -0.77 \\
\hline 16 & SGP KL-1561 & 24.06 & +4.02 & 11.16 & -1.32 & 10.50 & +3.02 & 15.24 & +1.93 \\
\hline 18 & SGP KL-1564 & 17.90 & -2.14 & 11.02 & -1.46 & 11.12 & +3.64 & 13.35 & +0.04 \\
\hline 19 & SGP KL-1562 & 21.12 & +1.08 & 10.58 & -1.90 & 9.18 & +1.70 & 13.63 & +0.32 \\
\hline 20 & SGP KL-1557 & 22.06 & +2.02 & 10.60 & -1.88 & 8.62 & +1.14 & 13.76 & +0.45 \\
\hline 21 & SGP KL-1545 & 15.90 & -4.14 & 11.84 & -0.64 & 8.56 & +1.08 & 12.10 & -1.21 \\
\hline NSR & & 1.96 & & 0.87 & & 0.76 & & 1.08 & \\
\hline
\end{tabular}


The most objective assessment of the studied varieties was revealed in 2020, when a more significant decrease in the fodder mass occurred in the standard (Pavlovsky 12 variety). This year, the yield exceeded the standard of 9 specimens by 5 percent or more. It can be assumed that these specimens have a high adaptive potential and increased stress resistance. They are, perhaps, less demanding on soil fertility and their productivity is less dependent on high temperatures and lack of moisture than the standard.

The results of seed yield are shown in Table 4. Depending on the biological characteristics of the specimens and the weather conditions that developed during the years of the study, there were significant fluctuations in seed yields, as well as in fodder mass. The highest yield over the years of research was formed by SGP KL-1538 specimen in the more favorable weather conditions in $2018(0.84 \mathrm{t} / \mathrm{ha})$, and the lowest in $2020(0.12 \mathrm{t} / \mathrm{ha})$. The average yield of this specimen over three years of observations was $0.38 \mathrm{t} / \mathrm{ha}$, which is $27.4 \%$ higher than the standard yield. The seed yield also varied in other specimens. Among the specimens shown in the table, Batyr variety turned out to be less yielding, the three-year average yield of which was $0.23 \mathrm{t} / \mathrm{ha}$.

Table 4. Seed yield of wheatgrass varieties in the collection nursery, $t /$ ha (sowing 2017, records in 2018-2020).

\begin{tabular}{|c|c|c|c|c|c|}
\hline Name of specimens & $\begin{array}{c}2 \text { year of } \\
\text { life }\end{array}$ & $\begin{array}{c}3 \text { year of } \\
\text { life }\end{array}$ & $\begin{array}{c}4 \text { year } \\
\text { insurance }\end{array}$ & $\begin{array}{c}\text { Average of 3 } \\
\text { years }\end{array}$ & $\begin{array}{c}\text { \% of } \\
\text { standard }\end{array}$ \\
\hline St. Pavlovsky 12 variety & 0.51 & 0.24 & 0.15 & 0.30 & 100.0 \\
\hline Batyr variety & 0.45 & 0.19 & 0.06 & 0.23 & 77.3 \\
\hline Karabalyk 202 variety & 0.73 & 0.10 & 0.39 & 0.29 & 97.0 \\
\hline $\begin{array}{c}\text { Shortandinsky broad- } \\
\text { spiked variety }\end{array}$ & 0.75 & 0.20 & 0.11 & 0.35 & 116.6 \\
\hline Burabay variety & 0.63 & 0.12 & 0.06 & 0.27 & 89.6 \\
\hline SGP KL-1565 & 0.63 & 0.09 & 0.08 & 0.27 & 89.4 \\
\hline SGP KL-1538 & 0.84 & 0.18 & 0.12 & 0.38 & 127.4 \\
\hline SGP KL-1540 & 0.43 & 0.08 & 0.09 & 0.25 & 81.5 \\
\hline SGP KL-1560 & 0.71 & 0.15 & 0.09 & 0.32 & 105.5 \\
\hline SGP KL-1561 & 0.64 & 0.20 & 0.16 & 0.33 & 110.5 \\
\hline SGP KL-1564 & 0.72 & 0.20 & 0.16 & 0.36 & 120.9 \\
\hline SGP KL-1562 & 0.51 & 0.13 & 0.15 & 0.26 & 86.8 \\
\hline SGP KL-1557 & 0.64 & 0.22 & 0.13 & 0.33 & 109.8 \\
\hline SGP KL-1545 & 0.53 & 0.14 & 0.12 & 0.26 & 87.3 \\
\hline SGP KL-1544 & 0.68 & 0.19 & 0.10 & 0.32 & 108.1 \\
\hline NSR & 0.062 & 0.017 & 0.012 & 0.030 & \\
\hline
\end{tabular}

\section{Conclusion}

According to the results of scientific research: experimental data were obtained on the evaluation of a new starting material of the comb-wheatgrass. In the 2017 collection nursery, out of 20 wheatgrass specimens obtained from Kazakhstan, 2 specimens exceeded the standard by more than $5 \%$ in terms of green mass according to average three-year data and 9 specimens exceeded the standard in dry 2020.

As can be seen from the tables, starting from the third year of life, there was a decrease in yield in terms of fodder and seed yield of all specimens. Thus, the standard yield of green mass, respectively, by years was $20.04,12.48$ and 7.48 t/ha, i.e., a decrease was noted by one third, in terms of seed productivity of $0.51,0.24$ and $0.15 \mathrm{t} / \mathrm{ha}$. In our opinion, the decrease in yield was due to a lack of moisture. In the severely arid year 2020, when only one cut was obtained, the yield of green mass of all specimens is significantly lower than the two previous years, the most significant decrease in the fodder mass occurred in the standard (Pavlovsky 12 variety). This year, the yield exceeded the standard of 9 specimens by 5 percent or more. It can be assumed that these specimens have a high adaptive potential 
and increased stress resistance, which should be continued to be used in research as more drought hardy specimens to improve the available varieties.

\section{Acknowledgments}

The authors express gratitude to N. I. Filippova, head of the perennial herb breeding department of the A. I. Baraev Research and Production Center of Grain Farming for the provided specimens from the collection of the center.

\section{References}

1. L. Salvati, L. Perini, A. Sabbi, S. Bajocco, Geographical Research, 50(2), 193 (2012)

2. B. S. Chauhan, G. Mahajan, R. K. Randhawa et al, Advances in agronomy, 123, 65 (2014)

3. A. Anand, S. Khetarpal, Plant Biology and Biotechnology. Springer, 729 (2015)

4. B. Sen, S. Topcu, M. Türkes et al, Climate Research, 52, 175 (2012)

5. A. I. Graux, G. Bellocchi, R. Lardy, J. F. Soussana, Agricultural and Forest Meteorology, 170, 114 (2013)

6. W. D. Dar, C. L. Laxmipathi Gowda, Journal of Crop Improvement, 27(2), 242 (2013)

7. K. B. Ruiz, S. Biondi, R. Oses et al, Agronomy for sustainable development, 34(2), 349 (2014)

8. Q. Sohail, H. Naheed, R. Mohammadi, Innovations in Dryland Agriculture. Springer, Cham, 257 (2016)

9. T. Absattar, A. Absattarova, N. Fillipova et al, Molecular breeding, 38(4), 1 (2018)

10. M. V. Derevyanikova, V. V. Chumakova, V. V. Kravtsov, Science news in the agroindustrial complex. Wheatgrass is a promising crop for cultivation in the southern regions of Russia, 2(11), 189 (2018)

11. A. V. Bukhteeva, Proceedings on applied botany, genetics and breeding, 169, 210 (2012)

12. A. N. Danilova, A. A. Sumbembayev, European Researcher, 74(5-1), 809 (2014)

13. G. K. Bulakhtina, A. V. Kudryashov, N. I. Kudryashova et al, RUDN Journal of Agronomy and Animal Industries, 13(2), 103 (2018)

14. A. V. Bukhteeva, L. L. Malyshev, N. I. Dzyubenko, A. A. Kochegina, Genetic Resources of wheatgrass - Agropyron GAERTN, 268 (2016)

15. S. V. Saprykin, V. N. Zolotarev, I. S. Ivanov, M. G. Ostrikova, IOP Conference Series: Earth and Environmental Science, 663(1), 012029 (2021) 